Іван МАНДРИК,

доктор історичних наук, професор, завідувач кафедри нової і новітньої історії та історіографї ДВНЗ «Ужгородський національний університет»

\title{
ЄДНІСТЬ ІСТОРИЧНОЇ ДОЛІ ТА СПІВРОБІТНИЦТВО НАРОДІВ І КРАЇН ЦЕНТРАЯЬНОÏ ЄВРОПИ
}

Стаття розкривае едність історичної долі та співробітниитвво народів Центральної Європи за попередні століттля, особливо за панування тут династії Габсбургів. Основну увагу приділено тому, що об'єднувало регіон, котрий завжди був сферою боротьби великих держав за зміцинення своїх позицій. Показано, що створення у 1991 роцъі регіонального Вишеградського об'єднання держав стало продовженням історичних традицій, циілком закономірним явищем.

Кдючові слова: Вищеград, Польща, Угорщина, Чехія, Словаччина, єдність, співробітництво, держава, незалежність, Центральна Європа, Габсбурги.

Статья раскрывает единство исторической судьбы и сотрудничество народов Центральной Европь в предьюущце века, особенно за период господства здесь династии Габсбургов. Основное внимание уделено тому, ито объединяло регион, который всегда был сферой борьбы великих государств за укрепление своих позиций. Показано, что создание в 1991 году регионального Вышеградского объединения государств стало продолжением исторических традиций, вполне закономерным явлением.

Ключевые слова: Вышеграл, Польша, Венгрия, Чехия, Словакия, единство, сотрудничество, государство, независимость, Центральная Европа, Габсбурги.

The article reveals the unity of historical destiny and cooperation of the peoples of Central Europe in the previous century, especially un- 
der the rule of the Habsburg dynasty here. Special attention is paid to that what had united the region, which has always been the area of combating between major states to strengthen their positions. It is shown that the establishment in 1991 of the regional Visegrad union of states was a continuation of historical tradition, which is quite natural phenomenon.

Keywords: Visegrad, Poland, Hungary, Czech Republic, Slovakia, unity, cooperation, state, independence, Central Europe, Habsburgs.

Минуле Центральної Європи характеризується різноманітністю, багатобарвністю. Це несло в собі альтернативні варіанти, врахування конкретних історичних реалій, але практика породила політичні та концептуальні помилки, а то й трагічні наслідки. Життя спонукае дослідників різних країн поглиблено вивчати досвід поляків, угорців, чехів і словаків стосовно мирного співжиття протягом багатьох століть. Тим більше, що продовжують зберігатися фактори, що і надалі породжують спільні проблеми, котрі вземопов'язують між собою цю частину континенту. Для того, щоб історія писалася правдиво, саме суспільство повинне орієнтуватися на наукову істину про своє минуле.

Добре відомо, що Вишеградська група країн виникла у 1991 році (Польща, Чехословаччина, Угорщина), але менше уваги приділяється причинам появи на теренах Центральної Європи такого регіонального об'єднання. 31993 року, після виникнення самостійної Словаччини, воно стало «четвіркою». Більше того, наступні чверть століття засвідчили його живучість, необхідність у наш час, бо його роль і вплив дише зростають у межах сучасного Європейського Союзу.

Нове керівництво цих країн (Вацлав Гавел, Дех Валенса, Йожеф Антал) чітко розуміло, що конче необхідно заповнити той зовнішньополітичний вакуум, котрий виник після ліквідації Варшавського договору, розпаду Радянського Союзу, об'єднання Німеччини, наростання напруги в сусідній Югославії. Додалися економічні виклики, а також проблеми національних меншин. Навіть міжнародні події найближчо- 
го майбутнього важко було передбачити. Правда, була проголошена смілива програма приєднання до НАТО і ЕС, але на початку 90-х років вона видавалася надто далекою перспективою.

Швидкі геостратегічні зміни, що відбувалися в регіоні та Европі в цілому протягом кінця 80-х - початку 90-х років XX століття, радикально трансформували зміст та основні напрями міжнародної політики країн Центральної Европи. Вони постійно перебували в епіцентрі протистояння між Сходом та Заходом. На етапі демонтажу соціалістичної системи, відразу після закінчення виведення радянських військ, йшлося про вибір майбутнього статусу цих країн. Нормалізація стосунків між Угорщиною, Чехословаччиною і Польщею була прискорена не лише мистецтвом дипломатів, а й об'єктивним бажанням держав регіону вступити до НАТО, членство в якому можливе лише за умов дружніх відносин між країнами, відсутності територіадьних претензій один до одного. Реалізація цих зовнішньополітичних напрямів була мождива лише в разі формування нової моделі відносин між державами регіону в рамках Вишеградської ініціативи.

Документ був підписаний представниками трьох держав 15 лютого 1991 року у лицарському залі Вишеградського замку, що розташований на березі Дунаю недалеко від угорської столиці - Будапешта. 3 того часу це регіональне об’єднання держав одержало назву «Вишеградська трійка», а з 1993 року, після роз'єднання Чехословаччини на Чехію і Словаччину, - «Вишеградська четвірка». Вибір угорського містечка був не випадковим, а глибоко символічним.

Ще у далекому 1335 році угорський король Карл Роберт уклав союз з чеським королем Яном, сприяв його примиренню 3 польським королем Казимиром І. У жовтні того ж року правителі Чехії, Польщі, Угорщини провели у Вишеграді конгрес, де уклали один з одним союзний договір. За Вишеградською угодою, Чехія за відмову від Подьщі отримує Сілезію. Три королі спільно виступили проти встановлення віденським двором митних бар'єрів проти їхніх товарів, а 
щоб їх реально уникнути, визначили нові шляхи сполучення для своїх купців (Буда - Естергом - Брно; Кошице - Брно; Кошице - північ, до Аьвова через Польщу) (3, с.53). Конгрес 1335 року у Вишеграді, його політичні та економічні рішення, мали показати усім зацікавленим народам тривалу історичну перспективу єдності дій цих країн, спільні риси їхньої долі, актуальність тіснішого регіонального співробітництва у різних сферах. Вишеградський замок був вибудований угорським королем Матяшем Корвіном (1458 - 1490 роки) і за його правління неодноразово був місцем зустрічей та укладення союзів з Чеським та Польським кородівствами. Саме Матяш у 1469 році здобуває Моравію, Сілезію, а богемські стани обирають Дадислава (1471-1516 роки) наступником (1,с.197). У 1478 році він об'єднується з Матяшем і за Оломоуцьким миром з 1490 року стає угорським королем. У XV столітті вважалося природним явищем, що чеська та угорська держави об'єдналися під скіпетром єдиного короля. Після смерті Матяша Корвіна (1490 рік) Дадислав чеський був обраний на угорський престол. Різноманітна співпраця тривала аж до XVII століття, коли шляхи Угорщини і Чехї розійшлися; єдиним зв'язуючим містком між ними і надалі залишався спільний монарх. Цими землями поступово заволоділи Габсбурги.

Князь Трансильванії Іштван Баторі (Стефан Баторій) у 1575 році на сеймі був обраний шляхтичами на вільний польський престол. У наступні роки він зарекомендував себе діяльним та успішним намісником, талановитим військовим діячем.

Починаючи з XVI століття, новим етапом в історії Центральної Европи стало встановлення панування династії Габсбургів. Саме завдяки їі державотворчій діяльності знову вдалося створити велике державне об'єднання, котре здатне було захистити цей обширний регіон (4, с.7). Спочатку йшлося про турецьку загрозу, пізніше російську та німецьку. У ході трьох поділів Польщі у другій половині XVIII стодіття та після Віденського конгресу 1814-1815 років частина 
польських земель ввійшла до складу Австрійської імперії. Проіснувала Австро-Угорська імперія аж до осені 1918 року. Едність регіону і його відмінність від решти континенту складалася протягом століть, але особливо рельефно це прослідковуеться у XVIII - XIX століттях. Нові штрихи додало і XX століття.

На погляд сучасного чеського дослідника Рудольфа Кучери, Габсбурзька монархія була наднаціональною монархією, наполовину німецькою, наполовину слов'янською, але одночасно й угорською, єврейською, італійською тощо $(4, c .8)$. Ії біди почалися після того, як до Центральної Европи проникли західні ідеї про доцільність створення єдиної національної держави, що привело регіон до цілковитої деструкції. Багато сучасних істориків сходяться на тому, що зникнення дунайської монархії можна вважати кінцем Центральної Европи. Трагедією стало те, що в кінцевому підсумку сюди просунулась східна російська імперія, яка на тривалий час захопила регіон, нав'язала йому свої руйнівні тоталітарні цінності (4, с.8).

Австро-угорська дуалістична угода 1867 року означала, що в обох половинах Габсбурзької імперії на папері фактично були встановлені конституційні порядки. Криза 60-х років XIX століття завершилася без великих політичних та соціальних потрясінь, тобто реальним компромісом верхів, панівних сил двох сильніших націй з понад десятка інших народів імперії. Виділивши дві нації (австрійських німців та угорську), угода тим самим загострила національні проблеми як монархії в цілому, так і кожної з двох їі частин. Компромісні рішення лише тимчасово стабілізували політичний розвиток імперіі. Особливе незадоволення висловлювали чехи та галицькі поляки, що входили до австрійської частини двоєдиної імперії. Територія сучасної Словаччини, як і нашого Закарпаття, починаючи з Х століття, була повністю інтегрована до складу Угорського королівства, де перебувала аж до 1918 року. Скажемо, що столиця Словаччини - Братислава до угорської революції 1848 року, під угорською назвою 
Пожонь, була місцем засідань Державних зборів Угорщини, тобто фактично іï столицею.

Для народів регіону характерною особливістю стала відсутність державності, втрачена уже багато століть тому (чехи, угорці, поляки), а словаки їі ніколи й не мали. Після Великої французької революції кінця XVIII століття прискорюється процес етнічної консолідації, виникнення національної ідеї, котра особливо зросла у ході революційних подій 1848-1849 років. У становленні національної ідеології велику роль зіграли культура й історія. Політика онімечення, русифікації, полонізації, мадяризації, котра систематично проводилася впродовж десятиліть, не привела до асиміляції інших народів регіону.

У ході капіталістичного розвитку Центральної Європи зростає родь єврейства, котре в економічному та інтелектуальному плані займало помітне місце. Однак у зв'язку 3 історичними умовами, у політичному житті воно не могло повністю зайняти місце національної буржуазіі. Чисельність єврейського населення неухильно зростала, з чим змушені були рахуватися державні керівники. У другій половині XIX століття заявив про себе й політичний антисемітизм, який не мав широкої соціальної основи. Тут скажемо, що у світлі сучасних міграційних проблем та европейських дискусій країни Вишеградської четвірки мають вдасний досвід стосовно свого ромського населення. У цих країнах цигани проживають протягом століть, вони пристосувалися до специфічних місцевих умов, як правило, знають мову більшості, сприймають основні культурні надбання, користуються громадськими та колективними правами, аде говорити про їхню цілковиту інтеграцію ще зарано, бо ромська проблема існує. Інша справа, що про неї сучасні політики та державні діячі воліють не говорити. Гадаємо, що керівники Угорщини, Чехії, Сдоваччини та Подьщі враховують і цей «досвід», коли так ревно виступають проти визначених квот Європейського Союзу щодо поселення до своїх країн трудових мігрантів 3 Азії та Африки. 
Протягом XIX - початку XX століття показовою була незавершеність демократичних перетворень, слабкість інститутів правової держави. Політична система ніяк не узгоджувалася 3 принципами демократії, бо у регіоні не було навіть натяку на народовладдя. Особливо це було характерно для Польщі, Угорщини, у меншій мірі для Німеччини та Австрії. Панівні сили, особливо аграрії, легально захищади свою подітичну владу тим, що обмежили участь збіднілих мас у виборах, відтіснили опозиційні сили, не бажали позбутися станових привілеїв. Політична опозиція, як правило, була непослідовною, оскільки заперечувала необхідність важдивих демократичних перетворень, проявляла нереальний підхід до основних суспільних проблем.

Характерною особливістю став факт наростання національних вимог народів регіону. Поряд з ними дунали зовнішні закдики до слов'янської єдності, побудови Серединної Європи, створення балканських союзів. Дійсно, народи регіону дуже залежали від зовнішніх обставин, від політики великих держав. У XIX столітті регіон став полем зіткнення інтересів Росії та Німеччини, що породжувало постійну міжнародну напругу. Слабим державним об'єднанням дедалі більше ставала Австро-Угорщина, що з плином часу ставало дедалі очевиднішим. Тут не були здійснені необхідні реформи. Так, відомий чеський політик Франтішек Палацький у праці “Idea státu Rakouského" висунув ідею федералізму та автономізації, що протиставлялася націоналізму малих народів імперії. Напередодні Першої світової війни подібні обіцянки не були сприйняті й з боку спадкоємця престолу Франца-Фердинанда.

Народи Центральної Європи проживають на просторі, що знаходиться між Німеччиною та Росією, тому їм протягом стодіть доводилося у кращому випадку приставати до того чи іншого берега. Це стало необхідним після посилення Габсбургів та створення об'єднаної Німеччини на Заході, зміцнення Московського царства та розширення Російської імперії на Сході. Після Першої світової війни обидві ці країни мали свої 
чіткі геополітичні інтереси у цьому регіоні, що й стало очевидним 3 кінця 30-х років та в ході Другої світової війни. За задумом творців Версальської системи, новостворені та відроджені Чехословаччина, Польща, у меншій мірі Угорщина, мали, по-перше, попередити просування східних комуністичних поглядів, по-друге, протистояти німецькому тискові.

У 1918 - 1920 роках на місці колишніх імперій виникли нові національні держави, чиї території часто не збігалися 3 етнічними кордонами. Національний склад населення цих країн залишався строкатим, до того ж у Польщі та Чехословаччині повторювалася національна подітика довоєнних часів. У 20-х - 30-х роках XX століття Польща та Чехословаччина проводили асинхронну політику у стосунках з Німеччиною і Радянським Союзом, що зашкодило обом країнам. Погіршувало між ними суперечки і так зване «тешенське питання», тобто територіальні претензії Польщі до Чехословаччини. Взагалі треба сказати, що у міжвоєнний період у регіоні утвердилися напівавтократичні режими ( окрім Чехословаччини), проходило постійне політичне коливання між демократією і автократією.

Перебування з XVI століття словаків в одній державі 3 чехами при династії Габсбургів сприяло розширенню їх економічних і культурних зв' язків, тим більше, що мова словаків і чехів була дуже близька. Перші проповідники ідей реформації серед словаків були з Чехї, Моравї, Сілезї (2, с.64).

Дружні відносини між поляками та угорцями, їхня взаємопідтримка впродовж століть, що збереглася у пам'яті обох народів, навіть стади легендарними.

Нарешті хочемо самі собі поставити запитання: чому центральноєвропейські країни так активно підтримують державну незалежність нашої України, їі європейські пріоритети? Попри інші причини, на нашу думку, це обумовлено тим історичним досвідом, що вони не хочуть мати такого неадекватного сусіда, яким може будь-коли стати Росія. Усе-таки між ними і Росією розташована Україна, яка бореться проти російських імперських зазіхань на чужі землі, у 
тому числі у Центральній Европі. Політики та еліта розуміють, що будь-яка зміна геоподітичної карти у Східній Европі неодмінно приведе до тиску на центрадьну частину нашого континенту.

Таким чином, історична спадщина тісно пов' язана 3 сучасністю і часто відповідає на їі запити. У минулому завжди можна знайти аналогії, оскільки традиції та пам'ять допомагають кожному новому поколінню вирішувати проблеми, які стоять перед ними.

Після Другої світової війни країни Центральної Европи стали сферою переважаючого впливу Радянського Союзу. Волелюбні народи намагались змінити тоталітарний тиск, навіть будувати соціалізм «з людським обличчям». Про це свідчать повстання у червні 1956 року у польському місті Познані, народна революція осені 1956 року в Угорщині, «Празька весна» 1968 року. Всі вони зазнали поразки, бо були придушені радянськими танками. Політичні та соціально-економічні зміни кінця 80-х - початку 90-х років також пройшли тут майже синхронно, мирно, знаменували поворот країн регіону до утвердження основ демократї та ринкової економіки.

Можна б навести ще й інші важливі особливості 3 історичного минулого регіону, котрі об'єднують його народи й країни, але ще багато складових потребують нових грунтовних наукових досліджень.

\section{Список використаних джерел}

1. Кіндер Г., Хільман В., Гегрт М. Всесвітня історія / Переклад 3 німецької. - К.: Знання - Прес, 2007. - 664c.

2. Пугач Е.П. История Словакии / Е.П. Пугач.- ХНУ, Харьков, 2013. - 344c.

3. Kučera Rudolf. Közép-Európa története egy cseh politológus szemével. Budapest: Korma Könyvek, 2008. - 165 o.

4. Gunst Péter (szerk.) Magyar történelmi kronológia. Budapest, 1970. -415 o. 